\title{
Identification of cCMP binding and activated proteins
}

\author{
Stefanie Wolfertstetter ${ }^{1 *}$, Elisabeth Schinner ${ }^{1}$, Franz Hofmann², Jens Schlossmann ${ }^{1}$ \\ From 6th International Conference on cGMP: Generators, Effectors and Therapeutic Implications \\ Erfurt, Germany. 28-30 June 2013
}

\section{Background}

cAMP and cGMP are well established second messengers and essential for numerous of (patho)physiological processes. These purine cyclic nucleotides activate PKA and PKG, respectively. So far, there was no evidence of further cyclic nucleotides acting as second messengers. Meanwhile the existence of cCMP was described [1]. Formation of the cyclic pyrimidine nucleotide cyclic cytidine 3',5'-monophosphate (cCMP) by cytidylyl cyclases is debated. cCMP induces relaxation of vascular smooth muscle via cGKI [2]. Furthermore, it was postulated that cCMP is relevant for cell growth [3] and blood cell function [4]. However, functions regulated by cCMP are mostly unknown.

\section{Results}

Our aim is to identify cCMP-binding and -acitvated proteins and to elucidate whether CCMP plays a role as second messenger. We confirmed that cCMP activates the purified cyclic nucleotide-dependent protein kinases cAK and cGK. Then we investigated the effect of cCMP on purified cyclic nucleotide-dependent protein kinases and on intact tissues of wildtype (WT) and cGKI-knockout (KO) mice, namely jejunum, lung and brain. We identified various protein kinases as CCMP-binding proteins in tissue lysates. cCMP stimulated cyclic GMP-dependent protein kinases in WT tissue lysates, however there was no stimulation of phosphorylation in $\mathrm{KO}$ tissue lysates.

\section{Conclusion}

These results indicate that $\mathrm{CCMP}$ could play a role in physiological processes in jejunum, lung and brain.

\footnotetext{
* Correspondence: stefanie.wolfertstetter@chemie.uni-regensburg.de 'Department of Pharmacology and Toxicology, University of Regensburg, Germany
}

Full list of author information is available at the end of the article

\section{Authors' details}

${ }^{1}$ Department of Pharmacology and Toxicology, University of Regensburg, Germany. ${ }^{2}$ FOR923, Institute for Pharmacology and Toxicology, TU, Munich, Germany.

Published: 29 August 2013

\section{References}

1. Newton RP, Salih SG, Salvage BJ, Kingston EE: Extraction, purification and identification of cytidine $3^{\prime}, 5^{\prime}$-cyclic monophosphate from rat tissues. Biochem J 1984, 21:665-673.

2. Desch M, Schinner E, Kees F, Hofmann F, Seifert R, Schlossmann : Cyclic cytidine 3',5'-monophosphate (cCMP) signals via cGMP kinase I. FEBS Lett 2010, 584:3979-3984.

3. Cheng YC, Bloch A: Demonstration, in leukemia L-1210 cells, of a phosphodiesterase acting on $3^{\prime}: 5^{\prime}$-cyclic CMP but not on $3^{\prime}: 5^{\prime}$-cyclic AMP or 3':5'- cyclic GMP. J Biol Chem 1978, 253:2522-2524.

4. Ervens J, Seifert R: Differential modulation by N4, 2'-O-dibutyryl cytidine 3':5'-cyclic monophosphate of neutrophil activation. Biochem Biophys Res Commun 1991, 74:258-267.

\section{doi:10.1186/2050-6511-14-S1-P78}

Cite this article as: Wolfertstetter et al.: Identification of cCMP binding and activated proteins. BMC Pharmacology and Toxicology 2013 14(Suppl 1):P78.
Submit your next manuscript to BioMed Central and take full advantage of:

- Convenient online submission

- Thorough peer review

- No space constraints or color figure charges

- Immediate publication on acceptance

- Inclusion in PubMed, CAS, Scopus and Google Scholar

- Research which is freely available for redistribution
() Biomed Central

\section{Biomed Central}

